\title{
Parent lithology and organic matter influence the hyporheic biota of two Mediterranean rivers in central Spain
}

\author{
Rubén Rasines-Ladero ${ }^{1, *}$ and Sanda Iepure ${ }^{1,2}$ \\ ${ }^{1}$ IMDEA Water Institute, Av. Punto Com, nº 2, Scientific Technological Park of the University of Alcalá, 28805, \\ Alcalá de Henares, Madrid, Spain. \\ 2 Institute of Speleology “Emil Racoviţă”, Romanian Academy, Clinicilor 5, 40006, Cluj Napoca, Romania. \\ * Corresponding author: ruben.rasines@imdea.org
}

Received: 06/03/2015

Accepted: 21/07/2015

\begin{abstract}
Parent lithology and organic matter influence the hyporheic biota of two Mediterranean rivers in central Spain

The hyporheic zone of stream ecosystems, located at the transition between surface channel and ground waters, exhibits patchy discontinuity on a longitudinal transect and induces changes in the structure and functioning of biotic communities. Nevertheless, the factors that influence biotic communities along spatial and temporal gradients remain poorly understood. This study aimed to characterise the diversity and spatial pattern distribution of Cyclopoida and Ostracoda from the hyporheic zone in relation to the riverbed sediment structure and the quantity of organic matter in two second-order rivers in central Spain, whose alluvium is derived from materials of contrasting geology (siliceous vs. carbonates). Both streams were found to be characterised by marked habitat heterogeneity along the hyporheic flow path, as reflected by the different lithology, riverbed permeability and distinct hyporheic biota assemblages. The results indicate that the alluvium riverbeds dominated by carbonates rocks and associated with high permeable riverbeds had slightly diverse hyporheic assemblages ( 25 species in all) with species of mixed ecology (stygobites/stygophiles/stygoxenes). Conversely, the siliceous alluvium riverbeds with low mineralised waters, associated with reduced permeability and relatively less active surface/ground water exchanges, displayed slightly lower diversity (23 species) with assemblages exclusively composed of stygophiles/stygoxenes. The results highlight the role of the riverbed substratum for the hyporheic biota and provide forthcoming approaches for depicting surfacesubsurface hydrological exchanges.
\end{abstract}

Key words: Hyporheic zone, diversity, organic matter content, sediment structure.

\section{RESUMEN}

Influencia de la litología y la materia orgánica sobre la biota hiporreica de dos ríos Mediterráneos en la zona centro de España

La zona hiporreica de los ecosistemas fluviales, situada entre las aguas superficiales y subterráneas, posee una gran heterogeneidad a lo largo de su perfil longitudinal que provoca cambios en la estructura y funcionamiento de las comunidades bióticas. Sin embargo, los factores que afectan a las comunidades bióticas a lo largo de un gradiente espacial y temporal son aún poco conocidos. En este estudio se pretende caracterizar la diversidad y el patrón de distribución espacial de los ciclopoides y ostrácodos de la zona hiporreica, de acuerdo a la estructura y cantidad de la materia orgánica contenida en el sedimento derivado de materiales geológicos diferentes (materiales carbonatados frente a silíceos) pertenecientes a dos ríos de segundo orden en el centro de España. Ambos ríos se caracterizaron por presentar una gran heterogeneidad de hábitats hiporreicos a lo largo de su perfil longitudinal, tal y como se refleja en cambios en la litología, la permeabilidad de los materiales que componen el cauce del río y las distintas comunidades bióticas asociadas. Los resultados indican que los cauces de los ríos dominados por carbonatos y con materiales de alta permeabilidad presentaron unas comunidades faunísticas levemente más diversas (25 especies en total) y con una ecología mixta (estigobiontes/estigofilas/estigoxenas). Por el contrario, los cauces de los ríos dominados por materiales siliceos con aguas poco mineralizadas y pocos intercambios entre agua superficiallagua subterránea, debido a una menor permeabilidad de los materiales, mostraron una menor diversidad (23 especies) con comunidades principalmente formadas por especies estigofilas y estigoxenas. Los resultados obtenidos ponen de manifiesto la importancia que tiene el origen de los materiales que conforman los sedimentos hiporreicos 
en la composición y distribución de las comunidades hiporreicas, así como para la determinación de procesos de intercambios hidrológicos entre las aguas superficiales y subterráneas.

Palabras clave: Zona hiporreica, diversidad, contenido de materia orgánica, granulometría.

\section{INTRODUCTION}

The hyporheic zone (HZ) is a band of saturated permeable sediments that lies adjacent to the channel of a river/stream where surface and ground waters mix (sensu Triska et al., 1989; Orghidan, 2010). The HZ is a highly dynamic ecotone. On a microscale, it is highly heterogeneous and results from the riverbed mosaic structure and surface-groundwater interactions (White et al., 1987; White, 1993; Dole-Olivier et al., 2009; Dole-Olivier, 2011). The primary production in the $\mathrm{HZ}$ depends on allochthonous inputs of organic matter: dead plants, organisms, microbes and products of their metabolism (Barrera-González et al., 2014). Organic matter fuels hyporheic biota, acts as a food resource and maintains trophic chains.

The origin of organic matter in the $\mathrm{HZ}$ varies from direct introduction into the stream from riparian vegetation (leaf litters and woods) to downwelling water or being buried during sediment transport events (Brunke \& Gonser, 1997; Franken et al., 2001; Elosegui \& Pozo, 2005; Findlay, 2006; Wallace et al., 2006; Cornut et al., 2012; Tonin et al., 2014). Leaf litters are further fragmented and transformed into fine particulate organic matter or dissolved organic matter by physical (i.e., turbulence and water flow) and biological (i.e., microbial activity and organism's breakdown) processes (Wallace et al., 2006; Pozo et al., 2009; Tonin et al., 2014). The second source of organic matter in the HZ is upwelling groundwater and surrounding floodplain soil washes (Franken et al., 2001; Tione et al., 2011; Trimmer et al., 2012).

A particular feature of $\mathrm{HZ}$ is its capacity to load organic matter along the riverbed, which is influenced mainly by the $\mathrm{HZ}$ size, the structural pattern of coarse gravel riverbeds and spatial segregation in the bed form distribution (Jones,
1997; Pozo et al., 2009; Cornut et al., 2012). Organic matter appears in the $\mathrm{HZ}$ as a solute on hyporheic waters and as decaying organic particles, dissolved molecules, free-living organisms and attached biofilms in sediments, and is further retrieved, transformed and mobilised by heterotrophic living organisms (Boulton et al., 1998). Organic matter is significantly concentrated in the upper sediment layers of downwelling zones, and its distribution along the $\mathrm{HZ}$ profile is patchy and influenced by the input rate, abiotic and biotic processing, sediment structure, grain size distribution and flood events, which imply bedload movements (Findlay et al., 1993; Brunke \& Gonser, 1997; Franken et al., 2001).

Early studies on the distribution of organic matter among sediments have indicated that it strongly influences the distribution of hyporheic meiofauna, as reflected in the heterogeneity of the community's diversity, abundance and distribution (Ward et al., 1994; Roca \& Wansard, 1997; Baker et al., 2000; Franken et al., 2001; Fowler \& Scarsbrook, 2002; Tione et al., 2011; Ruíz et al., 2013). Although several research studies have analysed the influence of hydrological and hydrochemistry characteristics on hyporheic biota community structures (Danielopol, 1989; Boulton et al., 1998; Gibert et al., 1994; Di Lorenzo et al., 2013; Iepure et al., 2013, 2014), the influence of substrate heterogeneity is poorly understood (Brunke \& Gonser, 1997; Franken et al., 2001; Dole-Oliver, 2011).

This paper aims to describe the effect of the small-scale distribution of HZ cyclopoid and ostracod crustaceans in relation to: i) heterogeneity in the spatial and temporal distribution of organic matter (in water and sediments); and ii) the substrate riverbed structure (particle size and lithology) in two small Mediterranean streams in central Spain with contrasting geological compositions. Our central hypothesis is that the exis- 


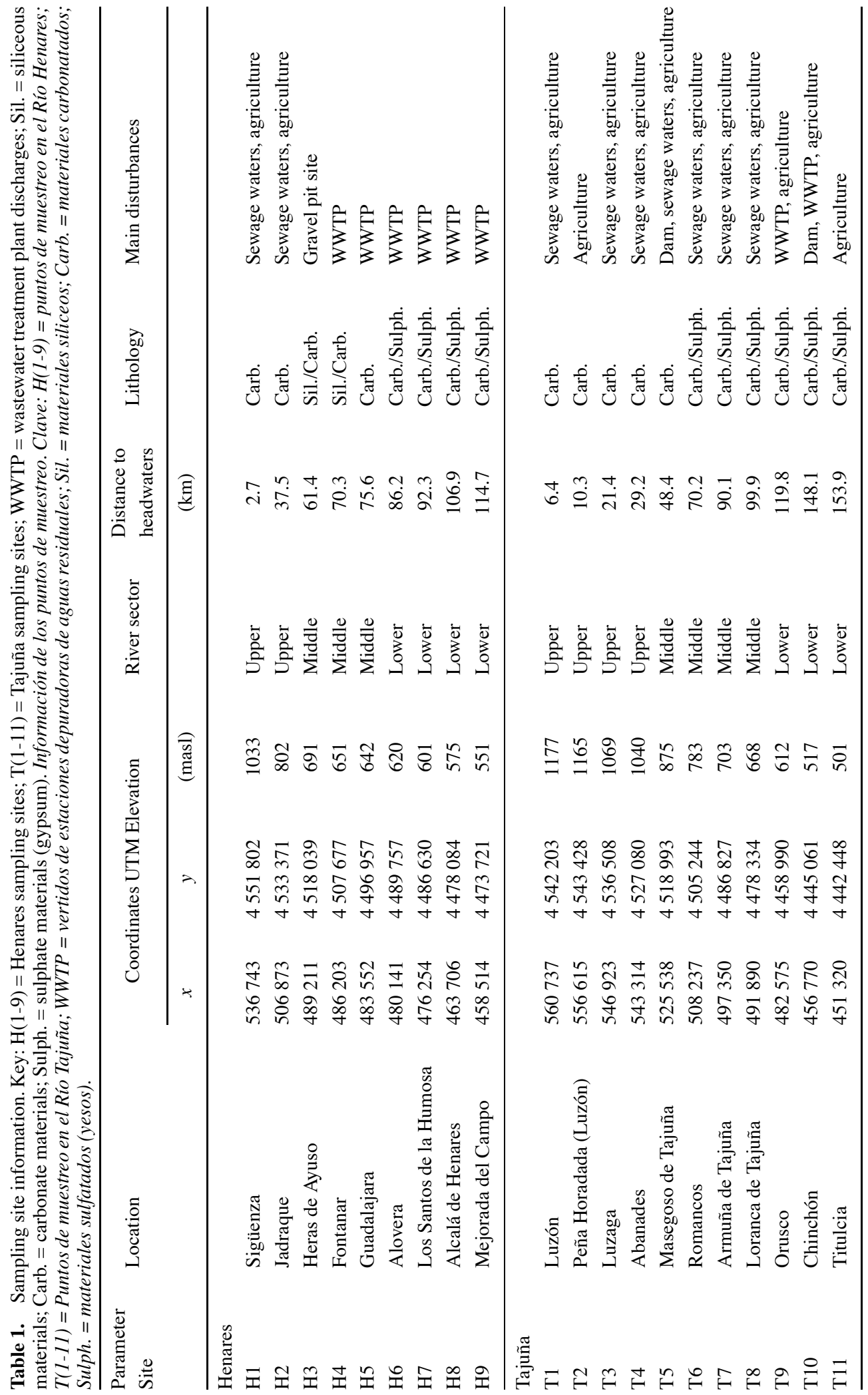


tence of a longitudinal gradient along a stream profile in the organic matter content distribution, local riverbed substrate composition and grain size results in a continuous adjustment in the diversity and density of hyporheic biota.

\section{METHODS}

\section{Study area}

Our study was conducted in two second-order streams (Henares and Tajuña) in central Spain that flow through the provinces of Guadalajara and Madrid (Fig. 1). Both streams are developed in Quaternary alluvium riverbeds, which are 1$1.5 \mathrm{~m}$ in depth and at least $10 \mathrm{~m}$ in width, whose substrates are composed principally of pebbles, gravel, sand and silt (Arribas et al., 2000; Camargo, 2006). The study streams were chosen for their contrasting riverbed structures, which comprise sediments derived from materials of distinct lithology: siliceous (Henares) vs. carbonates (Tajuña) (see Iepure et al., 2014).

The Henares $(\mathrm{H})$ stream is $158 \mathrm{~km}$ long with a catchment area of $4136 \mathrm{~km}^{2}$ and a mean annual discharge of $3.30 \mathrm{~m}^{3} / \mathrm{s}$. The water discharge measured during the surveyed period in 2012 was $3.24 \mathrm{~m}^{3} / \mathrm{s}$ in February and $4.92 \mathrm{~m}^{3} / \mathrm{s}$ in May (SAIH-Tajo, 2014). On the longitudinal transect, distinct channel types are recognized (cf. Montgomery \& Buffington, 1998): in the upper part, the channel is embedded in carbonate bedrocks with substrates of very high permeability (H1$\mathrm{H} 2$ ); in the middle sector (between $\mathrm{H} 3$ and $\mathrm{H} 5$ ), the channel bedrock overlays a mixture of carbonates and siliceous rocks; the riverbed substrates of the lower sector (between H6 to H9) develop in a mixture of carbonates and gypsumsulphates (Camargo, 2006; Garrote et al., 2008).

The Tajuña (T) stream is $254 \mathrm{~km}$ long with a catchment area of $2607 \mathrm{~km}^{2}$ and a mean annual discharge is $2.37 \mathrm{~m}^{3} / \mathrm{s}$. The water discharge measured during the surveyed period in 2012 was $2.63 \mathrm{~m}^{3} / \mathrm{s}$ in February and $2.75 \mathrm{~m}^{3} / \mathrm{s}$ in May (SAIH Tajo, 2014). The Tajuña stream channel develops fully on carbonated rocks (from T1 to $\mathrm{T} 4)$ or on a mixture of carbonated rocks with gypsum (downstream T7) that exhibit high and very high permeability (Garrote et al., 2008). The stream sector between T4 and T5 is dammed (La Tajera Lake, 450 ha, maximum depth $>10 \mathrm{~m}$ ) and is fed by Tajuña streamwater, run-off and precipitation. The dam is used for agriculture by regulating the Tajuña stream water level in the summer and alters the discharge to the main downstream channel (Castañeda-Buendia, 2011).

\section{Sampling design and methods}

The HZ of both studied streams was investigated at 20 sampling sites distributed along their entire courses after selecting nine sites in Henares (H19) and 11 in Tajuña (T1-11) (Fig. 1; Table 1). Surveys were conducted in two temporal replicates in winter (February) and spring (May) of 2012. All of the sites had a permanent surface flow; only one site was frozen in winter (T2). At each sampling point, the geographical coordinates and elevation were determined using a Garmin GPS-76.

Samples of interstitial water, sediments and organisms were retrieved from two replicates located in the middle of the channel at a depth of $20-40 \mathrm{~cm}$ by pumping $12 \mathrm{~L}$ of material with a Bou-Rouch device (Bou \& Rouch, 1967) and subsequently filtering this volume through a planktonic net $(63 \mu \mathrm{m})$. Any retained biological and sediment samples were fixed in $70 \%$ ethanol until laboratory processing. The biological samples were stained with Eosin Yellowish after fixation to aid the separation of the specimens from sediments and detritus.

During each survey period, channel and hyporheic waters were analysed in situ to determine their temperature (Hanna, checktemp1), dissolved oxygen (Crison, OXI-45P), pH (Crison, $\mathrm{pH}-25$ ) and electrical conductance (Crison, CM35 ). One litre of water from both the stream channel and the $\mathrm{HZ}$ were collected and filtered in the laboratory through a glass-fibre filter $(0.45 \mu \mathrm{m})$ to separate the dissolved organic carbon (DOC) fraction for the later analyses of 23 physicochemical parameters. For the present study, the following nine chemical parameters were retained (in $\mathrm{mg} / \mathrm{l}$ ): biological oxygen demand $\left(\mathrm{BOD}_{5}\right)$, chemical oxygen demand (COD), non- 
purgeable organic carbon (NPOC), total organic carbon (TOC), total carbon (TC), inorganic carbon (IC), carbonates $\left(\mathrm{CO}_{3}^{2-}\right)$, bicarbonates $\left(\mathrm{HCO}_{3}^{-}\right)$and sulphates $\left(\mathrm{SO}_{4}^{2-}\right)$ (see Supplementary information Table S1, available at www. limnetica.com).
The hyporheic organisms were retrieved from the sediments under an Olympus SZX-7 stereomicroscope and were counted and classified into classes and orders. Ostracods and cyclopoids were identified to the species level (Meisch, 2000; Dussart \& Defaye, 2001) and

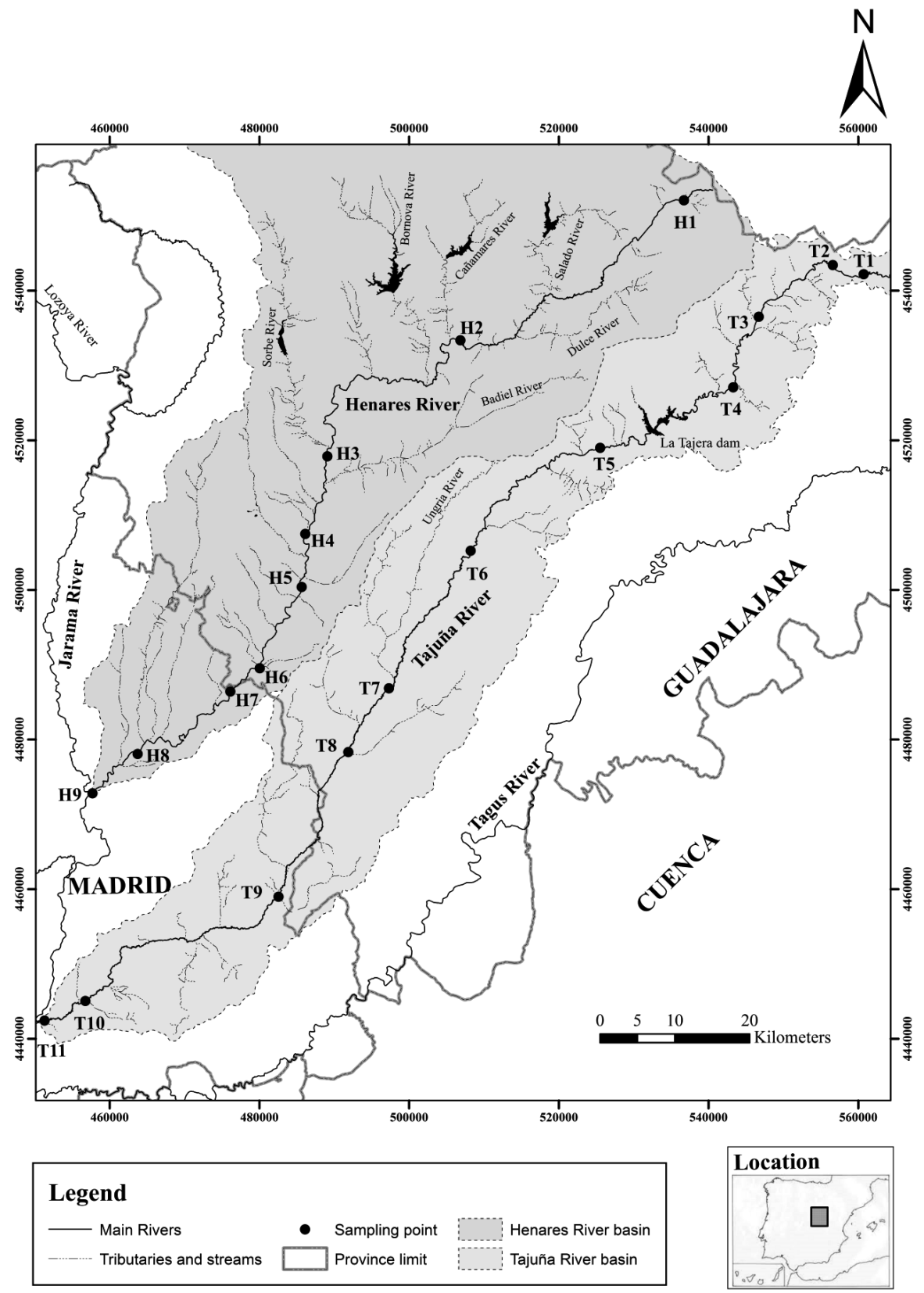

Figure 1. Location of the study area and distribution of sampling sites. Localización del área de estudio y distribución de los puntos de muestreo. 
classified into the following ecological categories: stygobites and non-stygobites (sensu Gibert et al., 1994).

After removing the organisms, the interstitial sediments were retained for granulometric analyses. The sediments were primarily dried in a P-Selecta oven at $50{ }^{\circ} \mathrm{C}$ for $24-48 \mathrm{~h}$. The substrates of each site were classified into five classes according to grain size: class 1 , very coarse sand $(\varnothing>1 \mathrm{~mm})$; class 2 , coarse sand

a)

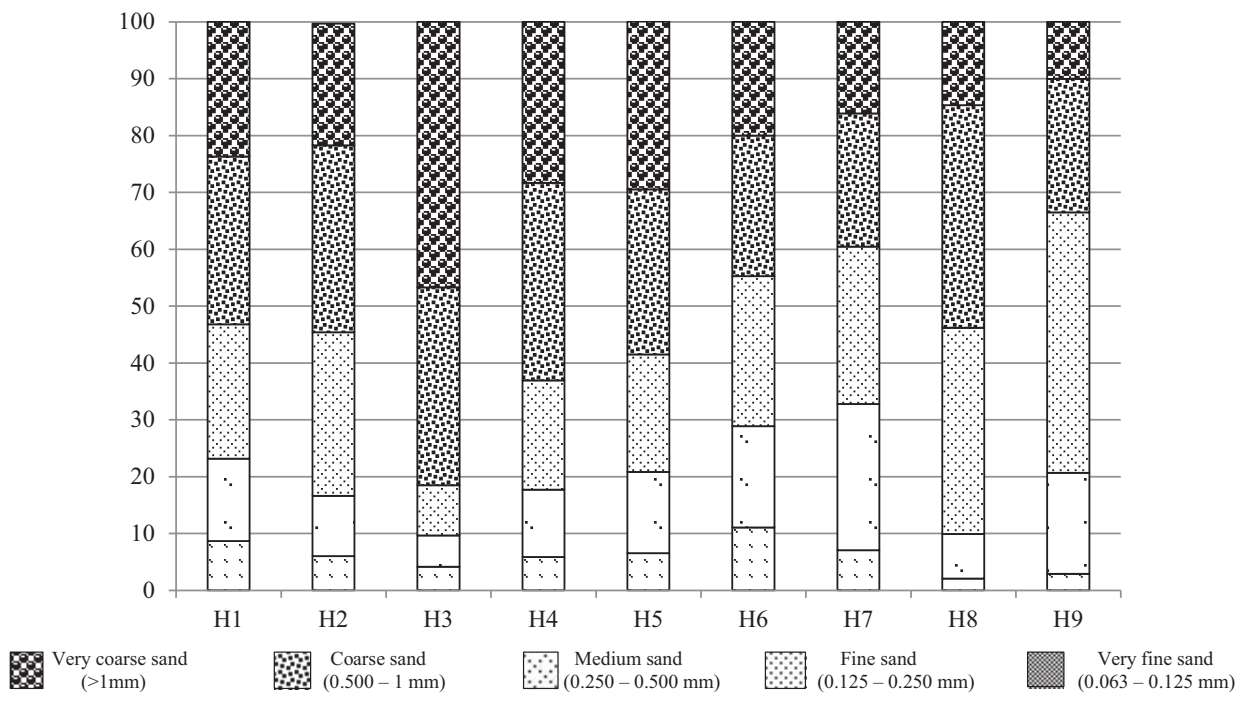

b)

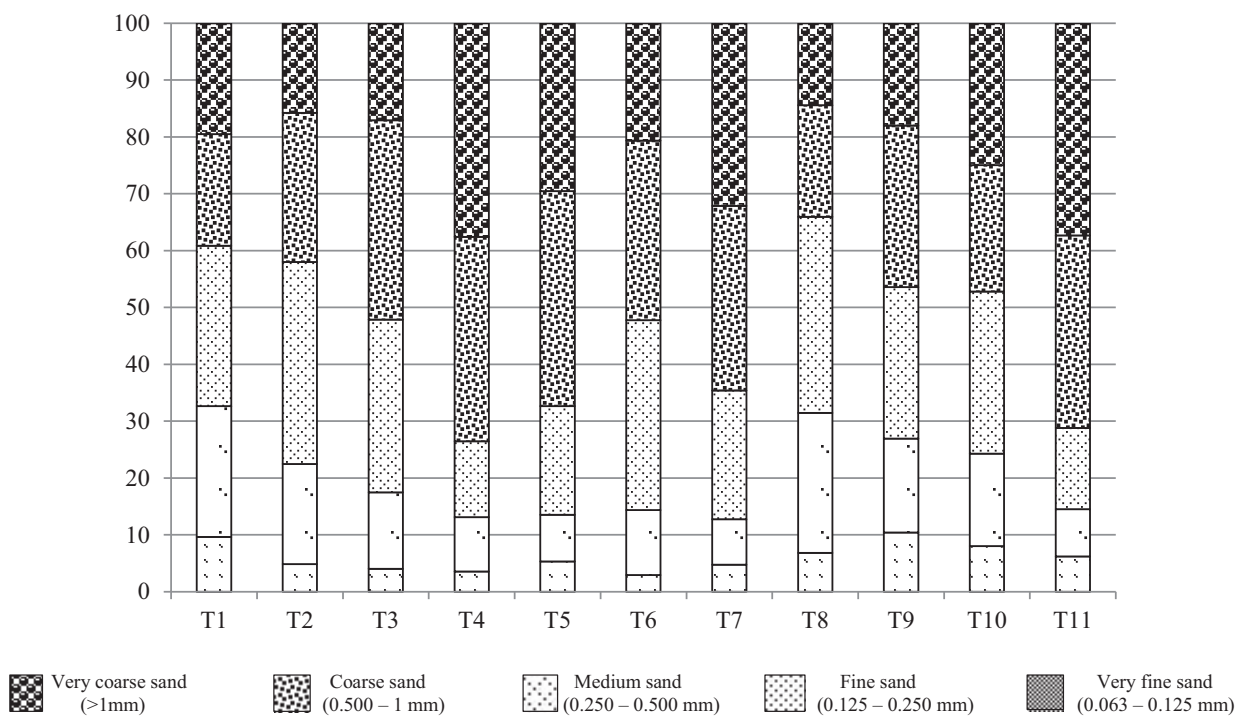

Figure 2. Spatial distribution for the averaged values (February-May 2012) of the granulometry fractions (in \%) along the hyporheic flow path of the Henares and the Tajuña Rivers. a) Henares River; b) Tajuña River. Key: H(1-9) = Henares River sampling points; $\mathrm{T}(1-11)=$ Tajuña River sampling points. Distribución espacial de los valores medios (Febrero-Mayo de 2012) de las fracciones granulométricas (en \%) a lo largo de la zona hiporreica de los ríos Henares y Tajuña. a) Río Henares; b) Río Tajuña. Clave: H(1-9) = puntos de muestreo en el Río Henares; T(1-11) = puntos de muestreo en el Río Tajuña. 
( $0.5 \mathrm{~mm}<\varnothing<1 \mathrm{~mm})$; class 3 , medium sand $(0.25 \mathrm{~mm}<\varnothing<0.5 \mathrm{~mm})$; class 4 , fine sand $(0.125 \mathrm{~mm}<\varnothing<0.25 \mathrm{~mm})$; and class 5 , very fine sand $(0.063 \mathrm{~mm}<\varnothing<0.125 \mathrm{~mm})$. To calculate the percentage of sediments fractions at each site, the weights of the analysed sediments were standardized to $26 \mathrm{~g}$.

The sediment fractions between 0.5 and $0.063 \mathrm{~mm}$ were further retained to measure the organic matter content by the loss on ignition (LOI) method (Heiri et al., 2001). The sediments were burned at $550{ }^{\circ} \mathrm{C}$ for $24 \mathrm{~h}$ in a muffle furnace (Heron, 8E-11). When calculating the percentage, the weight of the sediments before burning was standardised to $8 \mathrm{~g}$. Two replicates of each sample were used.

\section{Statistical analysis}

The environmental data were square roottransformed prior to the statistical analyses to meet the assumption of normality (tested by the Shapiro-Wilks test of normality).

The species richness was calculated for each site using the DIVERSE subroutine in the Primer (v.6) statistical software (Clarke \& Warwick, 2001). Multivariate distance-based redundancy analyses (db-RDA) were used to determine the ordination of the sampling sites based on the sediment configurations (granulometry), organic matter content (as LOI) and water environmental parameters (NPOC, TOC, $\mathrm{BOD}_{5}$ and COD). The environmental data were superimposed onto the db-RDA ordination as vectors to examine the contribution of the individual parameters to the dissimilarity of the clusters. The relationships between the 10 environmental variables and the abundance of hyporheic species of cyclopoids and ostracods were explored through canonical correlation analyses (CCA, Hammer et al., 2001) using the PAST 2.6 software. Additionally, Spearman rank correlations were applied to test the associations between the ranked environmental and biotic variables

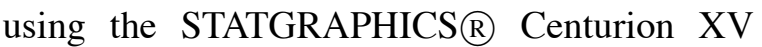
software (StatPoint Technologies, Inc., 2006). The significance of the differences in the parameters describing the cyclopoid and ostracod assemblages between both rivers and the two investigated seasons was determined by applying a Mann-Whitney U test in STATGRAPHICS $\mathbb{R}$ Centurion XV.

\section{RESULTS}

\section{Environmental parameters in the hyporheic zone}

An overview of the mean values of the environmental parameters measured at each sampling site is provided in Supplementary information Table S1. The Mann-Whitney U test $(p<0.05)$ results indicated that the physicochemical parameters of the surface waters (Table 2a) and hyporheic waters (Table 2b) of each stream varied significantly between the two temporal replicates and at the spatial scale. In Henares, the differences in the temperature, $\mathrm{EC}, \mathrm{pH}, \mathrm{NPOC}$, TOC, COD and $\mathrm{SO}_{4}^{2-}$ (Mann-Whitney $\mathrm{U}$ test, $p<0.05$, Table $2 \mathrm{~b}$ ) of the hyporheic waters among the sampling campaigns were statistically significant. In the Tajuña hyporheic waters, only the temperature, $\mathrm{DO}, \mathrm{CO}_{3}^{2-}$ and TOC presented significant differences (Table 2b). In the riverbed sediments, a greater accumulation of organic matter as LOI was detected in the winter season in both streams, although this difference was not statistically significant (Mann-Whitney U test, $p>0.05$ ).

Between the hyporheic waters of the two study streams, the $\mathrm{EC}$, temperature and $\mathrm{SO}_{4}^{2-}$ presented the most marked physicochemical variations (see Supplementary information Table S1). The values of temperature, EC and COD were higher in Henares, whereas the values obtained for $\mathrm{SO}_{4}^{2-}$ and DO were higher in Tajuña. The Mann-Whitney $\mathrm{U}$ test $(p<0.05)$ results also indicated that the concentrations of NPOC, TOC, $\mathrm{COD}, \mathrm{EC}$ and $\mathrm{HCO}_{3}^{-}$in the interstitial waters of Henares were significantly higher (Table $2 b$ ).

The organic matter content in the sediments slightly varied between both streams (overall mean values of $5.47 \%$ in Henares and $4.88 \%$ in Tajuña), but the difference was not statistically significant $(p>0.05)$. 
Table 2. Mann-Whitney U test results for the comparison of the physicochemical studied parameters between and within the studied rivers. a) Comparison of surface waters; b) comparison of hyporheic waters. Key: * parameter that presents significant differences $(p<0.05)$. Abbreviations: $\mathrm{T}=$ temperature; $\mathrm{EC}=$ electrical conductivity; $\mathrm{DO}=$ dissolved oxygen; $\mathrm{BOD}_{5}=$ biological oxygen demand; $\mathrm{COD}=$ chemical oxygen demand; NPOC $=$ non-purgeable organic carbon; $\mathrm{TOC}=$ total (dissolved) organic carbon; $\mathrm{TC}=$ total carbon; $\mathrm{IC}=$ inorganic carbon. Resultado del test $U$ de Mann-Whitney realizado para la comparación entre ríos y en cada uno de ellos de los parámetros fisicoquímicos estudiados. a) comparación en aguas superficiales; b) comparación en aguas hiporreicas. Clave: $*$ = parámetro estadísticamente diferente $(\mathrm{p}<0.05)$. Abreviaturas: $T=$ temperatura; EC = conductividad eléctrica; $\mathrm{DO}=$ oxígeno disuelto; $\mathrm{BOD}_{5}=$ demanda biológica de oxígeno; $\mathrm{COD}=$ demanda química de oxígeno; $N P O C=$ carbono orgánico no purgable; $T O C=$ carbono orgánico total; $T C=$ carbono total; $I C=$ carbono inorgánico.

a)

U-test values for the comparison of the studied physicochemical parameters (surface waters)

\begin{tabular}{lccccc}
\hline & Henares & Tajuña & Henares-Tajuña & Henares-Tajuña & Henares-Tajuña \\
\hline & Between surveys & Between surveys & Survey 1 & Survey 2 & Both surveys \\
\hline U-test & U-test & U-test & & U-test & U-test \\
\hline $\mathrm{T}\left({ }^{\circ} \mathrm{C}\right)$ & $40.5^{*}$ & $-60.5^{*}$ & $-31.5^{*}$ & -14.5 & -46.0 \\
$\mathrm{EC}$ & $-31.5^{*}$ & 3.5 & $-33.5^{*}$ & -23.5 & $-104.0^{*}$ \\
$\mathrm{pH}$ & -3.0 & $30.5^{*}$ & 22.5 & 9.5 & 67.0 \\
$\mathrm{DO}$ & $-23.0^{*}$ & $37.5^{*}$ & 20.0 & 25.0 & $81.0^{*}$ \\
$\mathrm{BOD}{ }_{5}$ & 0.0 & -27.0 & -4.5 & 22.5 & 36.0 \\
$\mathrm{COD}$ & $34.5^{*}$ & $-60.5^{*}$ & -21.5 & -5.5 & -27.0 \\
$\mathrm{NPOC}$ & 15.5 & -18.5 & $-31.0^{*}$ & $-39.5^{*}$ & $-137.5^{*}$ \\
$\mathrm{TOC}$ & $32.5^{*}$ & $-56.0^{*}$ & -45.5 & $-40.0^{*}$ & $-138.0^{*}$ \\
$\mathrm{TC}$ & -20.5 & $41.5^{*}$ & 22.0 & 21.0 & $-74.0^{*}$ \\
$\mathrm{IC}^{*}$ & $-24.5^{*}$ & $43.5^{*}$ & $28.5^{*}$ & 23.5 & $88.0^{*}$ \\
$\mathrm{CO}_{3}^{2-}$ & 1 & 2.5 & 3.5 & 1.5 & 9.5 \\
$\mathrm{HCO}_{3}^{-}$ & -13.5 & 28.5 & 18.5 & 17.5 & $73.0^{*}$ \\
$\mathrm{SO}_{4}^{2-}$ & -30.5 & -10.5 & -22.5 & -14.5 & -72.0
\end{tabular}

b)

U-test values for the comparison of the studied physicochemical parameters (hyporheic waters)

\begin{tabular}{|c|c|c|c|c|c|}
\hline & Henares & Tajuña & Henares-Tajuña & Henares-Tajuña & Henares-Tajuña \\
\hline & Between surveys & Between surveys & Survey 1 & Survey 2 & Both surveys (average) \\
\hline & U-test & U-test & U-test & U-test & U-test \\
\hline $\mathrm{T}\left({ }^{\circ} \mathrm{C}\right)$ & $40.5^{*}$ & $-60.5^{*}$ & $-30.5^{*}$ & -18.0 & -48.5 \\
\hline $\mathrm{EC}$ & $-31.5^{*}$ & 1.5 & -25.5 & -17.5 & $-75.0 *$ \\
\hline $\mathrm{pH}$ & $-10.0 *$ & 23.5 & 6.0 & 3.5 & 18.5 \\
\hline DO & -22.5 & $33.0^{*}$ & 7.5 & 21.0 & 56.5 \\
\hline $\mathrm{BOD}_{5}$ & 20.5 & -7.5 & $29.0^{*}$ & 1.5 & 58.0 \\
\hline COD & $39.5^{*}$ & 10.5 & $-45.5^{*}$ & $-48.5 *$ & $-168.0 *$ \\
\hline NPOC & $24.0^{*}$ & -24.5 & $-49.5^{*}$ & $-35.5^{*}$ & $-150.5^{*}$ \\
\hline TOC & $29.5^{*}$ & $-44.0 *$ & $-49.5^{*}$ & $-36.5^{*}$ & $-150.5^{*}$ \\
\hline $\mathrm{TC}$ & -10.5 & 13.0 & 20.0 & 16.0 & 72.5 \\
\hline IC & -13.5 & 16.5 & $30.5^{*}$ & 19.5 & $93.0 *$ \\
\hline $\mathrm{CO}_{3}^{2-}$ & -3.5 & $28.5^{*}$ & 18.5 & -1.5 & 31.0 \\
\hline $\mathrm{HCO}_{3}^{-}$ & -11.5 & -0.5 & 19.5 & 19.5 & $83.0^{*}$ \\
\hline $\mathrm{SO}_{4}^{2-}$ & $-31.5^{*}$ & -1.5 & -13.5 & -13.5 & -55.0 \\
\hline LOI & -7.0 & -3.5 & -14.5 & -6.5 & -43.0 \\
\hline
\end{tabular}



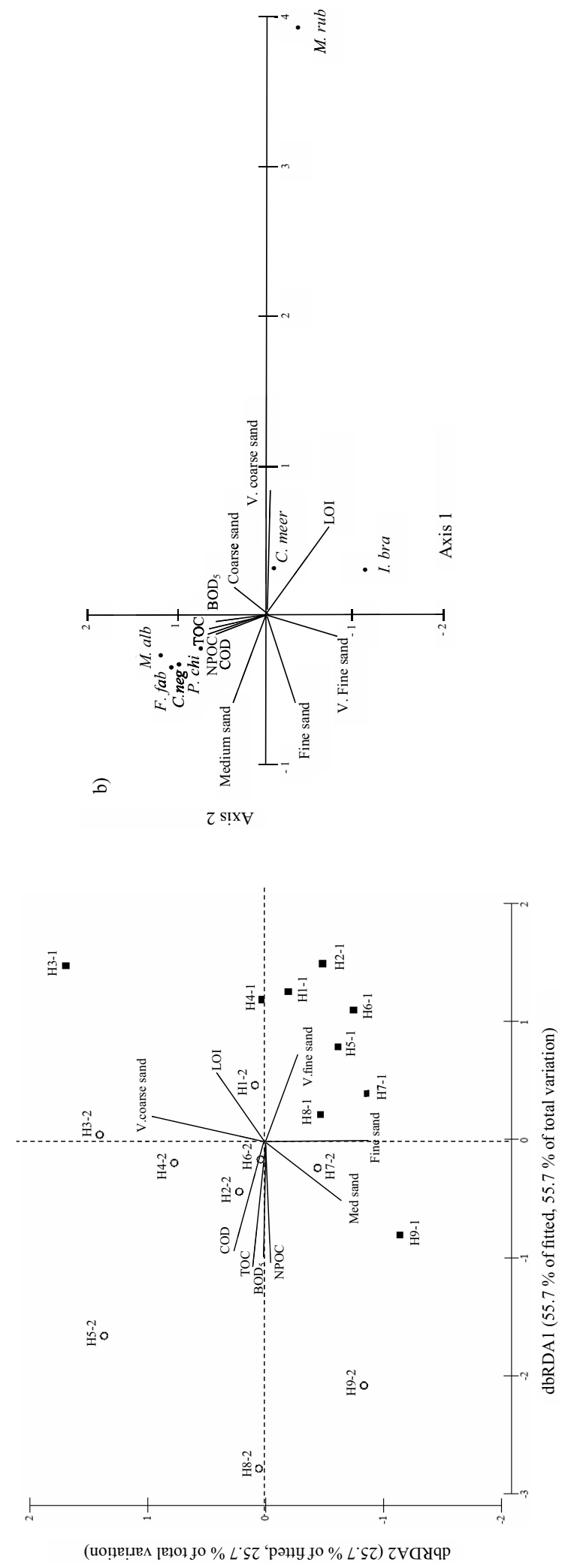

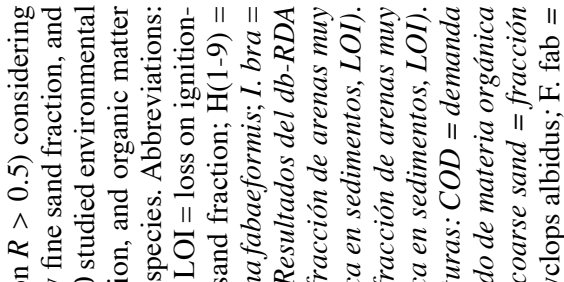

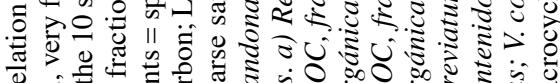

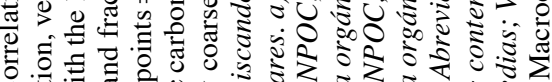

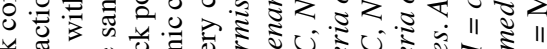

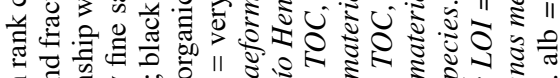

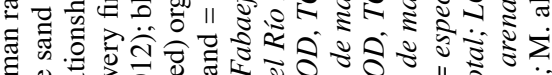

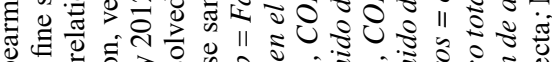
行

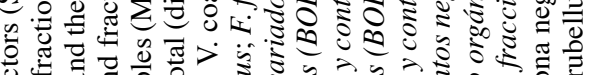

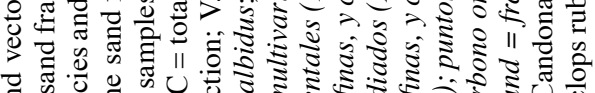

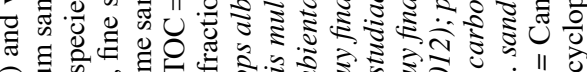

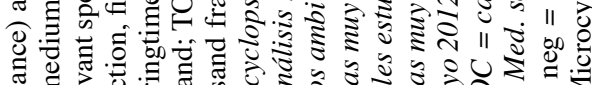

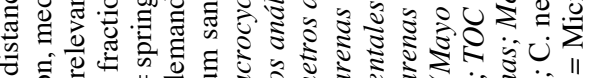

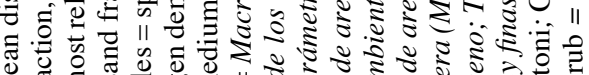

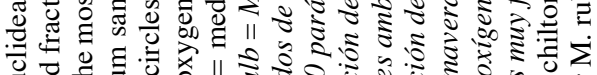

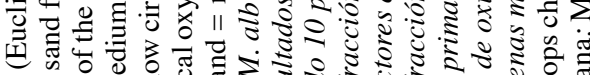

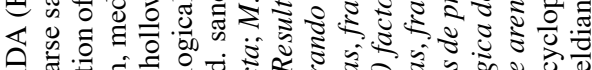

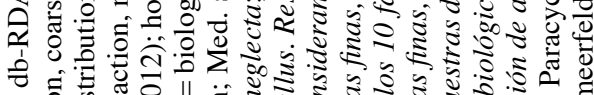
ช.

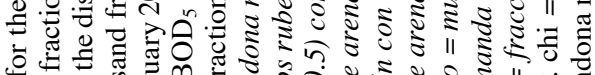
क्ष

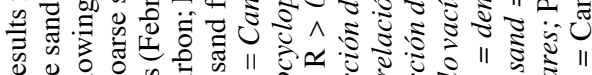

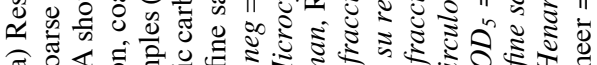

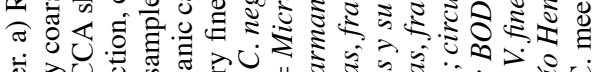

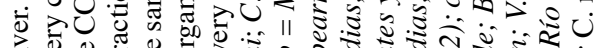

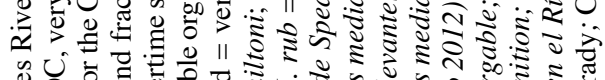

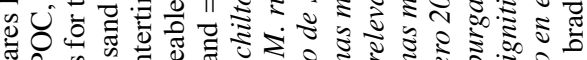

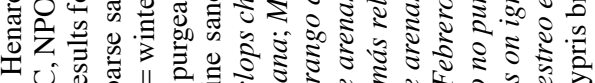

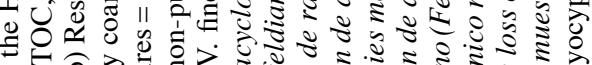

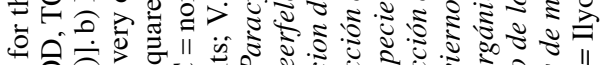

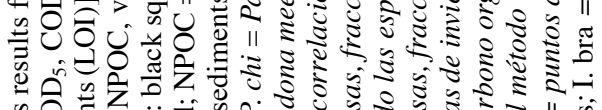

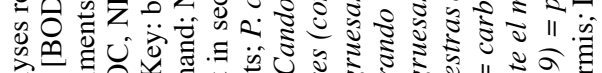

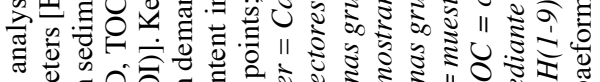
๘

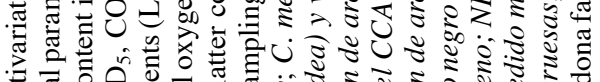

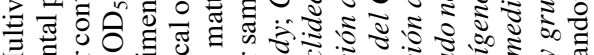

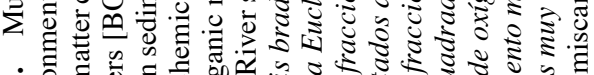
m.

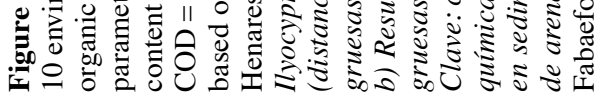




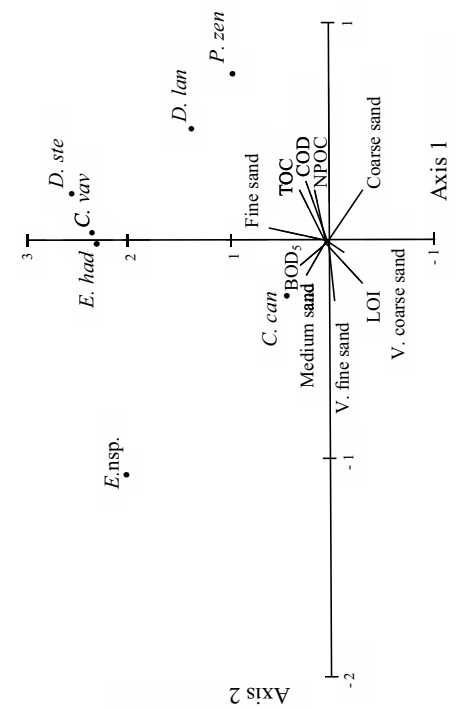

으믈

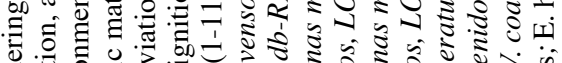

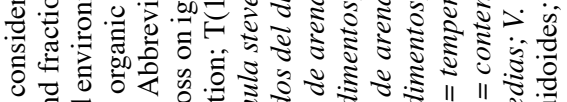

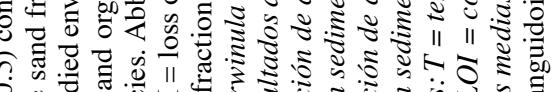

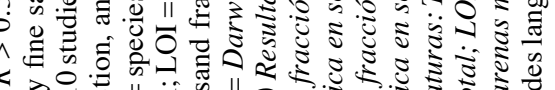

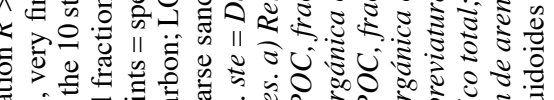

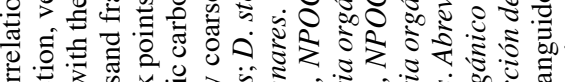

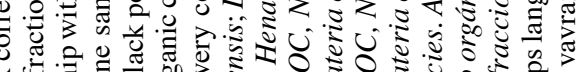

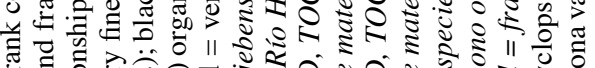
鹿. 可

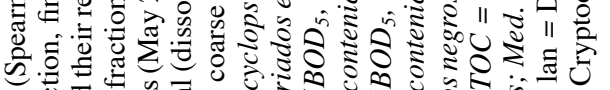

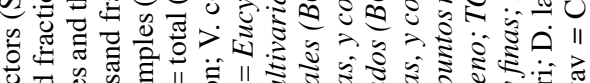

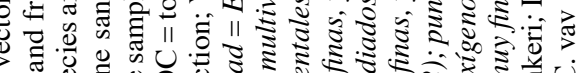

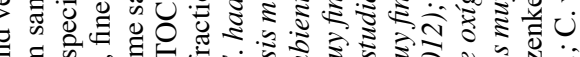

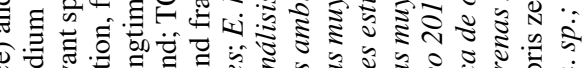

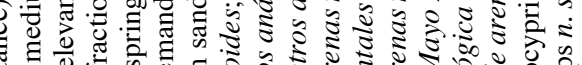

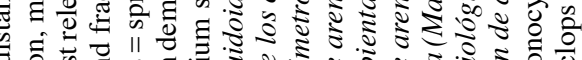

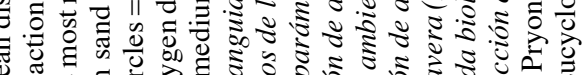
ช.

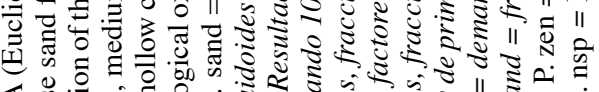

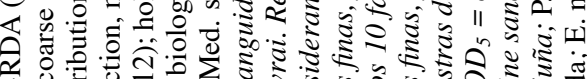

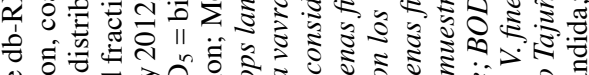

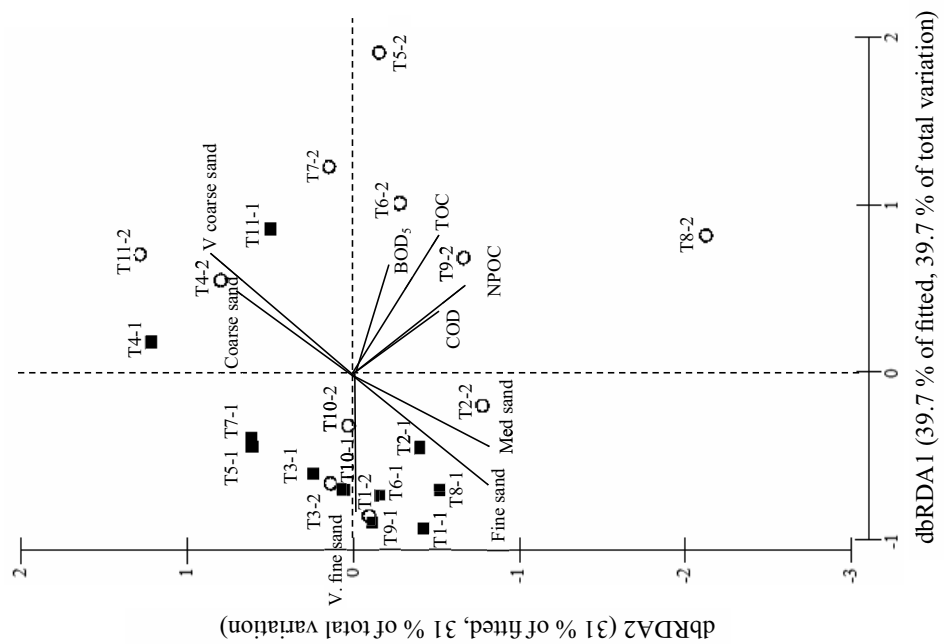

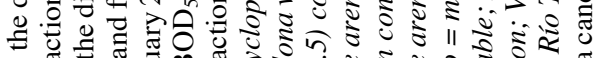
可

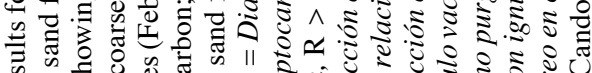
क人 ลे

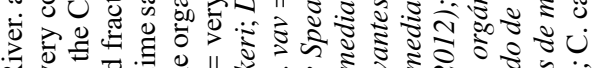
ช

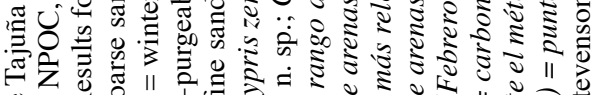

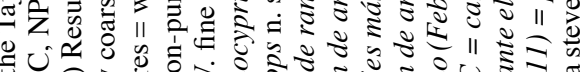

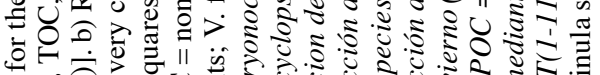
ôें⿰彳

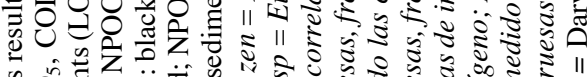

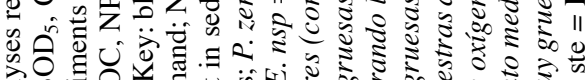

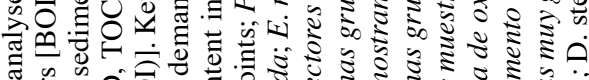

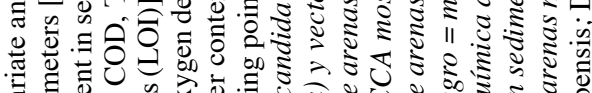

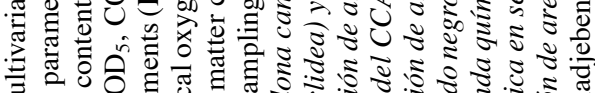

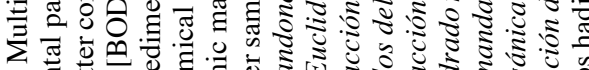
呐

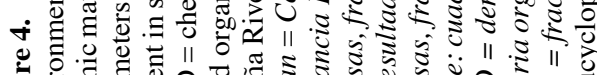

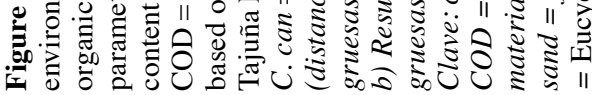


For both rivers, a significant longitudinal pattern was detected along their hyporheic flow paths (spatial scale) for the selected environmental parameters. The high mineralization and $\mathrm{EC}$ in the lower sectors of both rivers were quite evident (H6-H9 and T8-T11) due to the high contents of $\mathrm{Ca}^{2+}$ and $\mathrm{Mg}^{2+}$, which are characteristic of hard waters (see Supplementary information Table S1). The lower sector of Tajuña (T8-T11) was characterized by calcium sulphate-rich waters, which presented threefoldhigher levels than those observed upstream due to the presence of gypsum-sulphate rocks (see also Iepure et al., 2014). An increment in NPOC was noted in the hyporheic waters of both rivers (Spearman correlation, $R=-0.62, \quad p<0.05$ ) with decreasing elevation. Increases were also observed in the TOC in Henares $(R=-0.51$, $p<0.05)$ and the organic matter content in the sediments in Tajuña $(R=-0.65, p<0.05)$ with decreasing elevation. Oppositely, the organic matter content in the hyporheic sediment in Henares was lower when elevation decreased $(R=0.57, p<0.05)$.

\section{Grain size of $\mathrm{HZ}$ sediments}

Table 1 presents a general overview of the riverbed substrate characteristics at the 20 investigated hyporheic sites, and Figure 2 illustrates the spatial distributions of the grain sizes. The riverbed substrate structure of both streams was virtually similar in terms of grain size classes (Mann-Whitney U test, $p>0.05$ ). The percentage of very fine fractions $(0.125<\varnothing<0.063 \mathrm{~mm})$ in both rivers was higher in winter, whereas the percentages of the very coarse $(\varnothing>1 \mathrm{~mm})$ and coarse sand fractions $(0.5 \mathrm{~mm}<\varnothing<1 \mathrm{~mm})$ were higher in spring.

An alteration in the sediment grain size distribution along the longitudinal transect was detected in both streams (Fig. 2). In Henares, the percentage of the very coarse fraction positively correlated to the elevation $(R=0.63, p<0.05)$, whereas the medium sand fraction showed the opposite relationship $(R=-0.54, p<0.05)$ (Fig. 2a). Conversely, in the Tajuña River, several successive alterations in the substrate compo- sition in terms of grain size distribution were detected; i.e., at upstream T5, the riverbed substrates were dominated by the very coarse $(\varnothing>$ $1 \mathrm{~mm})$ and coarse fractions $(1<\varnothing>0.5 \mathrm{~mm})$, whereas the percentages of the finer fractions $(\varnothing<0.5 \mathrm{~mm})$ increased downstream at sites T5 and T10 (Fig. 2b).

\section{Abundances and diversity of Ostracoda and Cyclopoida}

In all, 2466 ostracod and cyclopoid individuals were collected from the HZ of both streams (1872 individuals in Tajuña and 594 specimens in Henares) (see Supplementary information Table S2, available at www.limnetica.com). Thirty-one species and subspecies (25 species in Tajuña and 23 in Henares) were identified. From them, 28 were ecologically classified as nonstygobites and three as stygobites (Eucyclops hadjebensis, Acanthocyclops venustus gr., and Acanthocyclops n. sp.).

The number of species and the population density of hyporheic cyclopoids and ostracods did not vary significantly over time between the two rivers (Mann-Whitney $\mathrm{U}$ test, $p>0.05$ ). However, both groups showed discontinuities along the hyporheic flow path in terms of the density and diversity of the populations and species turnover; e.g., along the Henares River, the maximum density was reached in the upstream sector at H2 (110 individuals, 5 species), with Diacyclops languidoides languidoides and Darwinula stevensoni contributing significantly to the increase in the density of the hyporheic population (see Supplementary information Table S2). Along the Tajuña River, the densities and species diversity of cyclopoids and ostracods also showed a strikingly discontinuous pattern along the hyporheic flow path, with a distinctly marked difference between the sites upstream of T8 (1460 individuals, 19 species) and the sites downstream of this site (412 individuals and 13 species) (see Supplementary information Table S2). The maximum densities in Tajuña were detected at several sites: at T2, where the maximum densities of Paracyclops imminutus and Potamocypris fulva were detected; at T4, 
where high densities of Paracyclops fimbriatus and Potamocypris fulva were observed; and at T10 where, the maximum densities of Acanthocyclops venustus gr. were identified (see Supplementary information Table S2).

\section{Relationship between the environmental conditions and the meiofauna}

The first two axes of db-RDA for the Henares stream explained $81.4 \%$ of the fitted variation, and the first axis showed major significance and separated the sites at a temporal scale (Fig. 3a). In winter, higher concentrations of $\mathrm{EC}, \mathrm{SO}_{4}^{2-}$, NPOC, TC, IC and $\mathrm{CO}_{3}^{2-}$ and high contents of the fine sand fraction and organic matter content characterised the water conditions and substrates of the Henares HZ. The CCA accounted for $48 \%$ of the total variance of the species data and highlighted the relationship between the environmental factors and distinct hyporheic species assemblages in the Henares River. The first axis of the CCA results were primarily an increasing gradient of the very coarse sand $(>1 \mathrm{~mm})$, the coarse sand fractions $(0.5-1 \mathrm{~mm})$, and the organic content (LOI) accounting for $18.73 \%$ of the species-environment relationships. Acanthocyclops robustus and Eucyclops hadjebensis had low scores on this first axis, indicating that they tended to be found in areas with low amounts of very coarse sands, whereas Microcyclops rubellus presented high scores on this axis being mainly related to the organic matter content (LOI) (Fig. 3b). The second axis was primarily an increasing gradient of the coarse sand fraction $(0.5-1 \mathrm{~mm})$ and accounts for an additional $18.54 \%$ of the species-environment relationships (Fig. 3b). The ostracod Pryonocypris zenkeri had a high score on this axis, suggesting that it is mainly found in coarse hyporheic sediments. Spearman rank correlation analyses supported some of the trends indicated by the CCA results, i.e., Microcyclops rubellus correlated significantly with a high organic matter content $(R=0.6, p<0.05)$ and a high percentage of very coarse sands $(R=0.85, p<0.05)$, Paracyclops chiltoni was associated with a high proportion of the medium sand fraction $(R=0.55, p<0.05)$, and Macrocyclops albidus was also related to a high proportion of the medium sand fractions $(R=0.51, p<0.05)$.

For Tajuña, the first two axes of the db-RDA explained $70.7 \%$ of the total variance (Fig. $4 a$ ) and similarly distinguished the sites according to the temporal variations in the environmental conditions. However, the level of distinctness was lower compared with that found for Henares. The CCA results (explaining $46.16 \%$ of the total variance) indicated that an increase in the proportion of coarse sands $(0.5-1 \mathrm{~mm})$ was markedly favourable for Paracyclops chiltoni and that a decrease in the proportion of the medium sand fractions $(0.25-0.5 \mathrm{~mm})$ was favourable for Candona candida and Pseudocandona albicans (Fig. 4b). Conversely, the second axis was mainly an increasing gradient of the fine sand fraction $(0.25-0.125 \mathrm{~mm})$ and accounted for $20.07 \%$ of the variance in the species-environment relationships (Fig. 4b). Eucyclops hadjebensis, Cryptocandona vavrai and Darwinula stevensoni presented high scores on this axis, suggesting that these taxa were mainly found in substrates with a high proportion of fine sediments. Spearman correlations indicated significant correlations only for Cryptocandona vavrai, which was positively related to the fraction of fine sediments $(R=0.44, p<0.05)$, and Pryonocypris zenkeri, which was negatively correlated with the organic matter content $(R=-0.5, p<0.05)$.

\section{DISCUSSION}

\section{Effects of granulometry and organic matter content on ostracod and cyclopoid distribution}

The data presented herein represent the first published attempt to compare the diversity (richness) and distribution of cyclopoids and ostracods in the $\mathrm{HZ}$ of two Mediterranean groundwater-fed streams of the Jarama basin with contrasting geological compositions: carbonates (Tajuña River) vs. siliceous (Henares River). This study was based on the assumption that the riverbed lithology and sediment granulometry create het- 
erogeneity in the physicochemical features along the longitudinal hyporheic flow path (Brunke \& Gonser, 1997; Harvey et al., 2012), which would alter the diversity and distribution of the hyporheic biota (Dole-Oliver et al., 2009, Gibert et al., 1994; Martin et al., 2009; Marmonier et $a l ., 2012$ ). Alterations in the physicochemistry of both rivers have been previously reported (Iepure et al., 2013) and provide complementary information to depict the water conditions and origin in the HZ. Although the riverbeds of both rivers contained different geological materials, the Mann-Whitney $U$ test did not indicate any significant differences in the structural texture between the siliceous substrate of the Henares and the carbonate substrates of the Tajuña. However, the multivariate db-RDA analysis indicated a clear distinction in the distribution of the grain size classes along the hyporheic flow path.

In Henares, the distribution of the major grain size sediments classes was more homogenous, as characterized by the slight predominance of medium and fine sands over coarse sands throughout the entire riverbed, which led to a smaller pore volume and a reduced permeability of hyporheic zone substrates (Arribas et al., 2000). These facts would hinder surface exchange processes, the slightly higher residence time of water in riverbed sediments and, subsequently, poorer hyporheic water renewal. Therefore, although the concentration of organic matter in the sediments of Henares was higher than that observed in Tajuña, the low riverbed permeability of Henares hampered the development of large cyclopoid and ostracod populations (see also Gibert \& Deharveng, 2002; Descloux et al., 2013). Nevertheless, in Henares, the main deterministic variables responsible for the presence of cyclopoids and ostracods were the low amounts of medium and coarse sands (i.e., favourable for Acanthocyclops robustus and Eucyclops hadjebensis) (Fig. 3b).

Alongside Tajuña, the riverbed substrates were dominated by the very coarse and coarse sand fractions $(\varnothing>0.5 \mathrm{~mm})$ as opposed to fine sands $(0.125<\varnothing<0.250 \mathrm{~mm})$. The texture of these types of sediments, which comprise large pore spaces, is associated with a high permeabil- ity and consequently offers suitable shelter habitats for hyporheic crustaceans. These features further amend not only the residence time of water in the $\mathrm{HZ}$ but also the dynamics of organic matter, such as its retention and input into sediments (Franken et al., 2001; Worral \& Burt, 2004; Ran et al., 2013). The HZ of Tajuña River was found to be present a significantly more diverse and abundant population of crustaceans, particularly cyclopoids, compared with that observed in Henares. The sediment fraction formed by coarse sands in the hyporheic zone of Tajuña River aided the maintenance of large species such as Paracyclops chiltoni, whereas fine sands $(0.125-0.25 \mathrm{~mm})$ were found to be mainly favourable for Eucyclops hadjebensis, Cryptocandona vavrai and Darwinula stevensoni (Fig. 4b). Nevertheless, the relationships between the distinct grain size classes and the organic matter content in the sediments were weak. Previous research conducted in Tajuña has certainly indicated that the higher cyclopoid and ostracod densities in the upper sectors of the river were more related to the water physicochemistry, mainly due to the presence of carbonates; whereas the presence of gypsumsulphates in the lower sector partially explained the observed scarcity or lack of species (Iepure et al., 2013, 2014). Our data also revealed that cyclopoids and ostracods were not uniformly distributed along the hyporheic flow path of Tajuña, which presented sectors of increasing population densities and diversities followed by abrupt decreases. This pattern indicates heterogeneity along the longitudinal transect, expressed by short-distance alterations to the hyporheic riverbed structure, as indicated by the grain size distribution (Fig. 2b). These discontinuities in the structural pattern of the hyporheic riverbed may be associated with the hyporheic habitats disruption, likely related to the presence of artificial dams along the river course, which are assumed to induce fluctuations in the river flow, geohydrochemical dynamics and thermal changes downstream (Iepure et al., 2014).

The within-rivers differences, as indicated the db-RDA, were found to be shaped by temporal changes in the sediment texture and organic 
content rather than spatial changes. A considerably more significant temporal distinction was found in the Henares River compared with Tajuña, resulting in a greater discrepancy among the sites of the two surveys. In winter, the hyporheic riverbed sites of Henares (except site H3) were characterised by a predominance of fine sediments (i.e., very fine and fine sands) and by a relatively high organic matter content, which accumulated in the stream bed sediments due to the base flow of the river. These tended to arrest the development of communities, particularly in terms of diversity, which was slightly higher in winter than in spring (19 vs. 15 species). Similarly, the density remained low in both seasons. The hyporheic communities of the Henares River were mirrored in winter by the dominance of species with large ecological valences and strong thermal tolerances, such as Microcyclops rubellus and Diacyclops languidoides languidoides among cyclopoids and Candona neglecta among ostracods (Reid et al., 1991; Pesce, 1994; Särkkä et al., 1998; Mezquita et al., 1999). In Henares, a marked shift toward a predominance of the medium to very coarse sand fractions was observed in springtime and was found to be associated with increased water channel discharge, which could restructure the sediments, deplete the sediment detritus and slightly increase the NPOC and DOC concentrations on the hyporheic waters (Worral \& Burt, 2004; Ran et al., 2013). This latter augmentation could also be associated with the high river productivity observed during this period. Consequently, the community structures of cyclopoids and ostracods in the Henares River changed slightly, and the population densities, particularly that of cyclopoids, increased. Among these, large species with sizes up to $1 \mathrm{~mm}$ (cf. Maier, 1994; Meisch, 2000; Dussart \& Defaye, 2001), such as Macrocyclops albidus and Paracyclops chiltoni, were well-represented, whereas the most dominant ostracods were Herpetocypris brevicaudata and Fabaeformiscandona fabaeformis.

In the Tajuña River, seasonal changes were also evident, but not as pronounced as those detected in Henares. The fine sediments fractions were more abundant in the low flow of winter, whereas a shift toward coarser and very coarse sands occurred in spring, when the discharge to Tajuña increased almost twofold. Consequently, the partition of the hyporheic community structure followed similar trends to those observed in Henares in terms of diversity, which was higher in winter, and density, which increased in spring. In Tajuña, several large populations of stygobites were detected and were represented by three species that are endemic to the Iberian Peninsula: i.e., Acanthocyclops venustus gr. and Acanthocyclops n. sp.; and to the Balearic Islands: i.e., Eucyclops hadjebensis (Gourbault \& Lescher-Moutoué, 1979); and frequently observed stygophile hyporheos ostracod Cryptocandona vavrai (see Supplementary information Table S2). Our findings confirm the previous assumption that a more significant upwelling would occur along the entire course of the Tajuña River, which would contribute to the shaping of hyporheic communities and to the sustaining of stable populations of obligate groundwater dwellers (Iepure et al., 2013). The patchy habitat heterogeneity in the Tajuña imprinted by substrate discontinuities contributed substantially to the sparse species distribution along the entire river course resulting in evident species turnover among sites, as reflected by the presence of single-site species, such as Candona vavrai and Eucyclops hadjebensis (at T1), Acanthocyclops robustus (at T9) and Paracyclops chiltoni (at T10). Noticeable dam-induced changes in the HZ communities of the Tajuña River were evident for a few species, as reflected by the smaller Paracyclops fimbriatus populations located downstream of the artificial reservoir (at T4). However, the opposite effect was obtained for Acanthocyclops venustus gr. (see Supplementary information Table S2).

\section{CONCLUSIONS}

The lithology and organic matter content in alluvium sediments of the $\mathrm{HZ}$ and the presence of cyclopoid and ostracod crustaceans were used to describe the hyporheic zone conditions of two Mediterranean rivers in central Spain. At 
the temporal and spatial scales, the composition of hyporheic cyclopoids and ostracods reflected the distribution and dominance of the grain size classes of the sediments and helped identify zones with distinct diversity and abundance. Although the observed diversity and abundance were altered mainly by the heterogeneity of the riverbed substratum along the hyporheic flow path and by the water physicochemistry, the organic matter loads of the sediments did not play a significant role. Changes in the cyclopoid and ostracod communities also indicated distinctness in the surface-subsurface water interactions since diversity of species with distinct ecological valences (stygobites vs. non-stygobites) increased in a more active $\mathrm{HZ}$ river channel, triggered by a riverbed dominated by coarse sediments of carbonate rocks that exhibited a higher potential of presenting upwelling spots along its flow path. The differences in the hyporheic assemblage composition and diversity between both rivers with contrasting geology indicated that in the same hydrographic basin, the hyporheic biota is a useful indicator of changes in the physical riverbed substrate structure. Further efforts to understand the factors responsible for the hyporheic fauna diversity and distribution in distinct typological categories of rivers will improve our understanding of the responses of the $\mathrm{HZ}$ to natural and anthropogenic disturbances.

\section{ACKNOWLEDGMENTS}

We thank Francisco Martínez, David Solé, Marta González de la Torre, Paulo Cassetari, Ilan Chocrón, Iván Ramos and Rosa Llorente for the laboratory processing of the samples and fieldwork, and Carolina Guillén, Sonia Herrera and Amaya Romero for the water chemistry analyses. We also wish to acknowledge to Juan Carlos Mateu and José Luis Barroso, from the Tagus River Confederation, for their technical and logistical support. The research funds were provided by the IMDEA-Water Institute (Madrid, Spain).

\section{REFERENCES}

ARRIBAS, J., S. CRITELLI, E. LE PERA \& A. TORTOSA. 2000. Composition of modern stream sand derived from a mixture of sedimentary and metamorphic source rocks (Henares River, Central Spain). Sedimentary Geology, 1333: 27-48.

BAKER, M. A., H. M. VALETT \& C. N. DAHM. 2000. Organic carbon supply and metabolism in a shallow groundwater ecosystem. Ecology, 81: 3133-3148.

BARRERA-GONZÁLEZ, L., J. RUEDA SEVILLA \& F. MESQUITA-JOANES. 2014. Estudio preliminar sobre la biodiversidad y ecología de la fauna intersticial en dos ríos mediterráneos: El Turia y el Palancia (Valencia, España). Boletín de la Real Sociedad Española de Historia Natural-Sección Biológica, 108: 125-135.

BOU, C. \& R. ROUCH. 1967. Un nouveau champ de recherches sur la faune aquatique souterraine. Les Comptes Rendus de Ácadémie des sciences $d u$ Paris, 265: 369-370.

BOULTON, A. J., S. FINDLAY, P. MARMONIER, E. H. STANLEY \& H. M. VALETT. 1998. The functional significance of the hyporheic zone in streams and rivers. Annual Review of Ecology and Systematics, 29: 59-81.

BRUNKE, M. \& T. GONSER. 1997. The ecological significance of exchange processes between rivers and groundwater. Freshwater Biology, 37: 1-33.

CAMARGO, J. 2006. Ecología y conservación del Río Henares y sus tributarios. Universidad de Alcalá. Alcalá de Henares (Madrid). Spain.

CASTAÑEDA-BUENDIA, D. 2011. Reobservación de la red geodésica de control de la presa de La Tajera. Proyecto de fin de carrera. Universidad Politécnica de Madrid, Spain.

CLARKE, K. R. \& R. M. WARWICK. 2001. Change in marine communities: an approach to statistical analysis and interpretation. $2^{\text {nd }}$ edition. PRIMERE. Plymouth. UK.

CORNUT, J., A. ELGER, A. GREUGNY, M. BONNET \& E. CHAUVET. 2012. Coarse particulate organic matter in the interstitial zone of three French headwater streams. Annales de Limnologie-International Journal of Limnology, 48(3): 303-313.

DANIELOPOL, D. L. 1989. Groundwater fauna associated with riverine aquifers. American Benthological Society, 8(1): 18-35. 
DESCLOUX, S., T. DATRY \& P. MARMONIER. 2013. Benthic and hyporheic invertebrate aaseemblages along a gradient of increasing streambed colmation by fine sediment. Aquatic Sciences, 75: 493-507.

DI LORENZO, T., F. STOCH \& D. M. P. GALASSI. 2013. Incorporating the hyporheic zone within the river discontinuum: Longitudinal patterns of subsurface copepod asseemblages in an Alpine stream. Limnologica, 43: 288-296.

DOLE-OLIVIER, M. J. 2011. The hyporheic refuge hypothesis reconsidered: a review of hydrological aspects. Marine and Freshwater Research, 62(11): 1281-1302.

DOLE-OLIVIER, M. J., F. MALARD, D. MARTIN, T. LEFÉBURE \& J. GIBERT. 2009. Relationships between environmental variables and groundwater biodiversity at the regional scale. Freshwater biology, 54: 797-813.

DUSSART, B. H. \& D. DEFAYE. 2001. Introduction to the Copepoda $2^{\text {nd }}$ edition. Guide to the identification of the microinvertebrates of the continental waters of the world. $N^{o} 16$. Backhuys Publishers. Leiden (Netherlands).

ELOSEGUI, A. \& J. POZO. 2005. Litter input. In: Methods to study litter decomposition: A practical guide. M. A. S. Graça and M. O. Gessner (eds.): 3-12. Springer, Dordrecht. Netherlands.

FINDLAY, S., D. STRAYER, C. GOUMBALA \& K. GOULD. 1993. Metabolism of streamwater dissolved organic carbon in the shallow hyporheic zone. Limnology and oceanography, 38(7): 19931493.

FINDLAY, S. 2006. Dissolved organic matter. In: Methods in stream ecology. F. R. Hauer and G. Lamberti (eds.): 239-248. Academic Press. London. UK.

FOWLER, R. T. \& M. R. SCARSBROOK. 2002. Influence of hydrologic exchange patterns on water chemistry and hyporheic invertebrate communities in three gravel-bed rivers. New Zealand Journal of Marine and Freshwater Research, 36: 471-482.

FRANKEN, J. M., R. G. STOREY \& D. DUDLEY WILLIAMS. 2001. Biological, chemical and physical characteristics of downwelling and upwelling zones in the hyporheic zone of a north-temperate stream. Hydrobiologia, 444: 183-195.

GARROTE, J., G. GARZÓN HEYDT \& R. TOM COX. 2008. Multi-stream order analyses in basin asymmetry: a tool to discriminate the influence of neotectonics in fluvial landscape development
(Madrid Basin, Central Spain). Geomorphology, 102: 130-144.

GIBERT, J., J. A. STANFORD, M. J. DOLE-OLIVIER \& J. V. WARD. 1994. Basic attributes of groundwater ecosystems and prospects for resesearch. In: Groundwater ecology. J. Gibert, D. L. Danielopol and J. A. Stanford (eds.): 1-42. Academic Press. London. UK.

GIBERT, J. \& L. DEHARVENG. 2002. Subterranean ecosystems: a truncated functional biodiversity. BioScience, 52(6): 473-481.

GOURBAULT, N. \& F. LESCHER-MOUTOUE. 1979. Faune des eaux souterraines de Majorque. ENDINDS:Publicació d'espeleologia, 5-6: 43-54.

HARVEY, J. W., J. D. DRIMMOND, R. L. MARTIN, L. E. McPHILLIPS, A. I. PACKMAN, D. J. JEROLMACK, S. H. STONEDAHL, A. F. AUBENEAU, A. H., SAWYER, L. G. LARSEN \& C. R. TOBIAS. 2012. Hydrogeomorphology of the hyporheic zone: Stream solute and fine particle interactions with a dynamic streambed. Journal of Geophysical Research, 117: G00N11.

HAMMER, O., D. A. T. HARPER \& P. D. RYAN. 2001. PAST: Paleontological statistics software package for education and data analysis. Palaeontologica Electronica, 4(1): 9 pp.

HEIRI, O., A. F. LOTTER \& G. LEMCKE. 2001. Loss on ignition as a method for estimating organic and carbonate content in sediments: reproductibility and comparability of results. Journal of paleolimnology, 25: 101-110.

IEPURE, S., V. MARTÍNEZ-HERNÁNDEZ, S. HERRERA, R. RASINES-LADERO \& I. DE BUSTAMANTE. 2013. Response of microcrustacean communities from the Surface-groundwater interface to water contamination in urban river system of the Jarama basin (central Spain). Environmental Science and Pollution Research International, 20(8): 5813-5826.

IEPURE, S., R. MEFFE, F. CARREÑO, R. RASINES-LADERO \& I. DE BUSTAMANTE. 2014. Geochemical, geological and hydrological influence on ostracod asssemblages distribution in the hyporheic zone of two Mediterranean rivers in central Spain. International Review of Hydrobiology, 99: 435-449.

JONES, J. B. 1997. Benthic organic matter storage in streams: influence of detrital import and export, retention mechanisms and climate. Journal of the North American Benthological Society, 16: 109119. 
MAIER, G. 1994. Patterns of life history among cyclopoids copepods of central Europe. Freshwater Biology, 31: 77-86.

MARMONIER, P., G. ARCHAMBAUD, N. BELAIDI, N. BOUGON, P. BREIL, E. CHAUVET, C. CLARET, J. CORNUT, T. DATRY, M. J. DOLEOLIVIER, B. DUMONT, N. FLIPO, A. FOULQUIER, M. GÉRINO, A. GUILPART, F. JULIEN, C. MAAZOUZI, D. MARTIN, F. MERMILLODBLONDIN, B. MONTUELLE, A. ROBERTSON, J. M. SANCHEZ-PÉREZ, S. SAUVAGE, A. TALEB, M. WANTZEN \& Ph. VERVIER. 2012. The role of organisms in hyporheic processes: gaps in current knowledge, needs for future research and applications. International Journal of Limnology, 48: 253-266.

MARTIN, P., C. DE BROYER, F. FIERS, G. MICHEL, R. SABLON \& K. WOUTERS. 2009. Biodiversity of Belgian groundwater fauna in relation to environmental conditions. Freshwater Biology, 54: 814-829.

MEISCH, C. 2000. Freshwater Ostracoda from Western and Central Europe. Süßwasserfauna von Mitteleuropa. Spektrum Ajademischer Verlagl. Heidelberg. Germany.

MEZQUITA, F., R. HERNÁNDEZ \& J. RUEDA. 1999. Ecology and distribution of ostracods in a polluted Mediterranean river. Paleogeography, Paleoclimatology, Palaeoecology, 148: 87-103.

MONTGOMERY,D. R. \& J. M. BUFFINGTON. 1998. Channel Processes, classification, and response. In: River Ecology and Management. R. Naiman and R. Billy (eds.): 13-42. Springler-Verlag, New York. USA.

ORGHIDAN, T. 2010. A new habitat of subsurface waters: the hyporheic biotope (translated original article). Fundamental and applied limnology, 176(4): 291-302.

PESCE, G. L. 1994. The genus Diacyclops Kiefer in Italy: a taxonomic, ecological and biogeographical up-to-date review (Crustacea Copepoda Cyclopidae). Arthropoda Selecta, 3(3-4): 13-19.

POZO, J., A. ELOSEGUI, J. DÍEZ \& J. MOLINERO. 2009. Dinámica y relevancia de la materia orgánica. In: Conceptos y técnicas de ecología fluvial. A. Elosegui y S. Sabater (eds.): 141-167. Fundación BBVA. Bilbao. Spain.

RAN, L., X. X. LU, H. SUN, J. HAN, R. LI \& J. ZHANG. 2013. Spatial and seasonal variability of organic carbon transport in the Yellow river, China. Journal of Hydrology, 498: 76-88.
REID, J. W., E. B. REED, J. V. WARD, N. J. VOELZ \& J. A. STANFORD. 1991. Diacyclops languidoides (Lilljeborg, 1901) s.l. and Acanthocyclops montana, new species (Copepoda, Cyclopoida), from groundwater in Montana, USA. Hydrobiologia, 218: 133-149.

ROCA, J. R. \& G. WANSARD. 1997. Temperature influence on development and calcification of Herpetocypris brevicaudata Kaufmann, 1900 (Crustacea: Ostracoda) under experimental conditions. Hydrobiologia, 347: 91-95.

RUÍZ, F., M. ABAD, A. M. BODERGAT, P. CARBONEL, J. RODRÍGUEZ-LÁZARO, M. L. GONZÁLEZ-REGALADO, A. TOSCANO, E. X. GARCÍA \& J. PRENDA. 2013. Freshwater ostracods as environmental tracers. International Journal of Environmental Sciences and Technology, 10(5): 1115-1128.

SAIH-Tajo (Sistema Automático de Información Hidrológica-Confederación Hidrográfica del Tajo). 2014. Accessible url: http://saihtajo.chtajo.es/

SÄRKKÄ, J., L. LEVONEN \& J. MÄKELÄ. 1998. Harpacticoid and cyclopoid fauna of groundwater and springs in southern Finland. Journal of Marine Systems, 15: 155-161.

STATPOINT TECHNOLOGIES, INC. 2006. Statgraphics $\AA$ Centurion XV User Manual.

TIONE, M. L., J. C. BEDANO \& M. T. BLARASIN. 2011. Comunidades de invertebrados en aguas subterráneas y su relación con variables ambientales. Ecología Austral, 21: 087-100.

TONIN, A. M., L. U. HEPP, R. M. RESTELLO \& J. F. GONÇALVES JR. 2014. Understanding of colonization and breakdown of leaves by invertebrates in a tropical stream is enhanced by using biomass as well as count data. Hydrobiologia, 740: 79-88.

TRIMMER, M., J. GREY, C. M., HEPPELL, A. G. HILDREW, H. LANSDOWN, H. STAHL \& G. YVON-DUROCHER. 2012. River bed carbon and nitrogen cycling: State of play and some new directions. Science of the total environment, 434: 143158.

TRISKA, F. J., V. C. KENNEDY, R. J. AVANZINO, G. W. ZELLWEGER \& K. E. BENCALA. 1989. Retention and transport of nutrients in a thirdorder stream in Norhwestern California: hyporheic processes. Ecology, 70(6): 1893-1905.

WALLACE, J. B., J. J. HUTCHENS JR \& J. W. GRUBAUGH. 2006. Transport and storage of FPOM. In: Methods in stream ecology. F. R. Hauer and G. 
Lamberti (eds.): 249-271. Academic Press. London. UK.

WARD, J. V., J. A. STANFORD \& N. J. VOELZ. 1994. Spatial distribution patterns of crustacean in the floodplain aquifer of an alluvial river. Hydrobiologia, 287: 11-17.

WHITE, D. S. 1993. Perspectives on defining and delineating hyporheic zones. Journal of the North
American Benthological Society, 12(1): 61-69.

WHITE, D. S., C. H. ELZINGA \& P. HENDRICKS. 1987. Temperature patterns within the hyporheic zone of a Northern Michigan river. Journal of the North American bethological society, 6: 85-91.

WORRAL, F. \& T. BURT. 2004. Time series analysis of long-term river dissolved organic carbon records. Hydrological processes, 18(5): 893-911. 